\title{
ZOÖGEOGRAFIE VAN SURINAME ${ }^{1}$ )
}

\section{DOOR}

\author{
D. C. GeijSKes
}

Zoögeografie is de kennis over de verspreiding van de dieren in vroegere en de tegenwoordige tijd. De invloeden die tot hun verspreiding geleid hebben kunnen zeer verschillend zijn. Voor het maken van zoögeografische gevolgtrekkingen moet men dus niet alleen de dieren systematisch kennen, maar ook hun verspreiding weten. Het is begrijpelijk, dat bij onze gebrekkige kennis van de dierenwereld van Suriname, deze analysering slechts voor de beter bekende diergroepen mogelijk kan zijn. Het betreft hier de zoogdieren, de vogels, enkele insectengıvepen en sommige slakken.

\section{ALGEMENE BESCHOUWINGEN}

Degene die enigszins bekend is met de dierenwereld van Suriname weet, dat de diergezelschappen er niet overal dezelfde zijn. De dieren welke men aan het strand vindt ziet men in het binnenlandse hoogbos zelden of in het geheel niet. Maar ook in de bossen treft men verschillen aan tussen de fauna's der diverse bostypen. Het bos in de rivierdalen herbergt een andere dierenwereld dan de bossen op de bergen. Er is ook verschil tussen oostelijk en westelijk Suriname en tussen het noordelijk en het zuidelijk deel van dit land.

Enkele voorbeelden mogen dit toelichten.

De kwatta-aap (Ateles paniscus) bewoont het gehele binnenland, bij voorkeur de bergstreken. De baboen of brulaap (Alouatta seniculus) komt eveneens in het gehele binnenlandse bos voor, maar bewoont vooral de bossen in de rivierdalen; hij komt ook in de kustvlakte voor, in de gemengde ritsenbossen zelfs tot bij de zee.

1) Lezing welke op de 23e Ledenvergadering van de „Natuurwetenschappelijke Studiekring voor Suriname en de Nederlandse Antillen", op 27 April 1956, werd gehouden. 
Poema (Puma concolor) en jaguar (Panthera onca) leven beide in de binnenlandse bossen, waarbij de eerste aan de bergen de voorkeur geeft. De jaguar komt bovendien in het kustterrein voor, waar hij zelfs op het strand de zeeschildpadden aanvalt.

Van de vier soorten stinkvogels of aasgieren die in Suriname leven, komt de zwarte gier (Coragyps atratus) uitsluitend in het kustgebied voor, terwijl de drie andere soorten in het binnenland gevonden worden; van deze dringt er maar één tot in het kustterrein door.

De gevreesde makkaslang (Lachesis mutata) is een kenmerkend dier van het hoge binnenlandse bos en ontbreekt in het kustterrein. De ratelslang (Crotalus terrificus) leeft, behalve in het binnenlandse savannebos, ook in bepaalde kustzwampen (o.a. van de Commewijne en de Marowijne).

Onder de padden is Bufo marinus, de grote Surinaamse pad, een bewoner van de kuststreken, terwijl de gehoornde reuzenpad (Ceratophrys cornuta) een typisch element vormt van de heuvelachtige terreinen in het binnenlandse bos.

Bij de zoetwaterslakken van het geslacht Pomacea (= Ampullaria), waarvan 5 soorten in Suriname gevonden zijn, komt één soort $(P$. dolioides) alleen in het kustgebied voor. De andere vier leven in het binnenland, en één ervan dringt ook in het kustland door $(P$. glauca).

Onder de insecten zijn dergelijke gevallen bekend bij de libellen (Odonata). Ischnura fluviatilis, een kleine blauwe waterjuffer, treft men alleen in de kusstreek aan, tot in de savannegordel. Nauwverwante soorten van het geslacht Metaleptobasis worden in het binnenland gevonden, met één soort tot in de bossen van de kustritsen.

Sprekender is wellicht de verspreiding van de muskieten. Anopheles aquasalis is een kustlandbewoner. Anopheles darlingi treedt langs de oevers van de rivieren in het binnenland op, maar nadert langs de Marowijne de monding van die rivier. De laatstgenoemde muskiet is de vector van malaria in het binnenland van Suriname.

Deze weinige voorbeelden illustreren voldoende een bepaald geografisch beeld van de kustfauna van Suriname, dat blijkt te zijn samengesteld uit twee elementen: een binnenlandse fauna welke ten dele in de oude en jonge kustvlakte doordringt, en een typische kustfauna die langs de kust, hetzij uit het Oosten, hetzij uit het Westen, Suriname is binnengedrongen. - Een derde groep van door de mens ingevoerde dieren, laten we hier buiten beschouwing.

De herkomst van de binnenlandse fauna is moeilijker vast te stellen. We kunnen hier globaal onderscheiden: een fauna van het laaglandbos, een bergland-fauna, een savanne-fauna en een hydro-fauna in de rivieren en boskreken.

Een groot gedeelțe van het Surinaamse binnenland kan tot het 1 a a g$\mathrm{l}$ a n d b o s gerekend worden. De dieren die kenmerkend zijn voor dit milieu, sluiten voor een groot deel aan bij de fauna, die gevonden wordt in het Amazonebekken.

Voorbeelden onder de zoogdieren zijn: luiaarden, miereneters, gordeldieren, navelzwijnen (pingo, pakira), bosherten (koeriakoe, prasara-dia), tapir, verschillende apensoorten (brulaap, gewone kesi-kesi of mekoe, monki-monki of doodskopaapje, sagoewintje) en knaagdieren (koni-koni, 
paca), jaguar, tijgerkatten, boshond, wasberen (kwasi-kwasi, Potos), marters en buidelratten.

Vele vogelsoorten behoren ook hiertoe: anamoes (Tinamidae), roofvogels, hoenderachtigen (powies, wakago en marail) (Cracidae), krieko's of rallen, duiven, papegaaien, koekoeken, uilen, nachtzwaluwen, kolibries, Trogon's, ijsvogels, toekans, spechten, boomkruipers, mierenvogels, Cotinga's, Tyrannidae, zwaluwen, banane-bekkies (Icteridae), Thraupidae en vinkachtigen.

Naar schatting kan ongeveer $50 \%$ van de diersoorten van Suriname tot deze categorie gerekend worden.

De fauna van het be r g l a n d is nog weinig onderzocht wegens de moeilijke toegankelijkheid van het terrein en omdat het binnenland van Suriname weinig hoge bergen van enige uitgestrektheid bezit. De hoogste top is $1280 \mathrm{~m}$; het Wilhelmina-gebergte heeft verschillende toppen van $1000 \mathrm{~m}$ en hoger, doch het overige bergland wisselt van 200$800 \mathrm{~m}$. Het zandsteenplateau van de Tafelberg verheft zich van 500 tot $1000 \mathrm{~m}$.

Dieren die zich alleen tot deze bergen beperken, kennen wij maar weinig, maar vermoedelijk zijn er verschillende van zulke soorten aanwezig onder de vogels, reptielen en amphibiën. Het rotshaantje (Rupicola rupicola) kan als voorbeeld genoemd worden en wellicht ook de belvogel (Procnias alba).

Reeds werd gewezen op de kwatta-aap en de poema als bewoners van het gebergte, maar ook de apensoorten kwatta-swageri (Chiropotes chiropotes) en berg-kesikesi of mutsaap (Cebus olivaceus) behoren tot deze categorie.

Bovendien klimmen vele soorten uit het laagland de bergen op. Zo treft men op elke bergtop ,,buffelpaden" van de tapir aan en sporen van het boshert (Mazama nemorivaga), terwijl het pingo-navelzwijn op de Tafelberg is aangetroffen.

In de bergbeken leven verschillende vissoorten, insecten en slakken, die typisch zijn voor deze wateren en waaronder elementen gevonden worden met een grote verspreiding in het Andes-gebergte. Hiertoe behoren onder de libellen soorten van het geslacht Heteragrion, Protoneura, Perilestes en Perithemis, en onder de zoetwaterslakken Pomacea crassa. $\mathrm{Zij}$ dalen zelfs tot in de vlakte af, mits de ecologische omstandigheden die zij behoeven (o.a. koel water over rots en zandbodem) aldaar voorkomen.

De savannen zijn faunistisch door een aantal soorten gekenmerkt. Het savannehert (Odocoileus gymnotis) en de savannehond (Dusicyon thous) zijn voorbeelden. Ook de kleine savannepatrijs (Colinus cristatus sonnini) en wellicht verschillende kleinere vogelsoorten, alsmede de ratelslang en enige weinig bekende hagedissen en kikkers, vormen karakteristieke soorten voor deze terreinen. Opvallend zijn kleine termietenheuvels, terwijl veel bijen- en wespensoorten hier voorkomen. Er zijn 20 soorten libellen bekend die typisch zijn voor de savannen.

Verschillende van deze diersoorten komen ook op de savannen in Venezuela voor, andere op die van Brazilië of van de Grote Antillen. Verscheidene soorten zijn echter kenmerkend voor de Guyana's zelf. 
Tenslotte kan nog een enkele opmerking gemaakt worden over de fauna van de Surinaamse rivieren. Uit de beschikbare gegevens over de waterbewonende schildpadden en kaaimannen, vissen, waterinsecten en waterslakken blijkt, dat deze fauna is samengesteld uit wijdverspreide soorten en uit endemismen. Er zijn verschillen tussen Oost en West bekend. Een grote gladvis bijv. is alleen uit de Corantijn bekend geworden en verder van de rivieren van Brits Guyana. De zoetwaterslakken vertonen meer overeenkomst met die van Frans Guyana dan met die van Brits Guyana. Merkwaardig is nog dat zowel in de Essequibo als in de Oayapok, resp. in Brits en Frans Guyana, soorten van de Amazone zijn gevonden (Caiman niger bijv.), hetgeen wijst op een tijdelijke samenhang in de regentijd van deze stromen met de Amazone-zijrivieren. De Surinaamse rivieren zijn echter door de permanente waterscheiding aan de zuidgrens, buiten een dergelijke directe invloed van de Amazone-fauna gebleven. Er komen wel soorten in voor die zij met het Amazonestelsel gemeen hebben, maar ter verklaring van dit verschijnsel kan wellicht beter een verspreiding van de Guyanas naar de Amazone aangenomen worden dan omgekeerd.

\section{ENDEMISCHE SOORTEN}

Endemisch worden hier de diersoorten genoemd die alleen van Suriname of, in ruimere zin, alleen van de Guyana's bekend zijn. Van verschillende soorten is dit beperkte voorkomen onzeker omdat ook de nabuurlanden nog weinig onderzocht zijn. Bij de vogels kunnen zeker een aantal soorten als echte endemismen worden onderkend. Volgens de nieuwe vogellijst van Haverschmidt (1955) behoren van de 536 van Suriname bekende soorten ongeveer 100 tot de endemismen (17\%). PARKer (1935) constateerde dat onder de reptielen en amphibiën van Brits Guyana ongeveer 30\% der soorten endemisch voor de Guyana's is. Van de libellen zijn ongeveer $27 \%$ der soorten endemisch (GEIJSKEs).

TATE (1939) vermeldt ca 100 zoogdiersoorten voor de Guyana's; van deze groep ,there remain between ten and fifteen forest species which show a greater or lesser degree of endemism in the Guiana area" (p. 157). Volgens deze auteur bestaat er geen geografische vermenging tussen de fauna van Guyana en die van Rio Negro. De wijd-verspreide, algemeen voorkomende zoogdiersoorten maken ongeveer $50 \%$ van het totaal uit.

Uit deze gegevens blijkt dat het percentage endemische soorten bij verschillende diergroepen wisselen van 10 tot $30 \%$.

\section{GEOGRAFISCHE GROEPEN}

Voor de Surinaamse fauna zijn 5 geografische groepen te 
onderscheiden, die - voor zover de thans beschikbare gegevens reiken - er op wijzen dat deze fauna

a. grotendeels aansluit bij die, voorkomende in het noordelijk Amazone-bekken; dit betreft vooral de dieren van het laaglandbos (40-50\%)

(Amazonean)

$b$. voor een gedeelte soorten bezit die alleen in de Guyana's gevonden zijn (endemische soorten); deze komen in alle landschappen voor $(10-30 \%)$

(Guyanean)

c. voor een geringer gedeelte directe of indirecte aansluiting te zien geeft met de bergfauna van de Andes; dit betreft de bergdieren (ca 20\%)

(Andean)

$d$. voor een nog kleiner gedeelte verwantschap vertoont met de fauna van Midden-Amerika; dit zijn ook bergvormen (ca 5\%)

(Central American)

$e$. slechts enkele soorten bezit die relatie hebben met de dierenwereld van de Antillen; dit zijn de savanne-dieren en kustbewoners (ca 3\%)

(Antillean)

De Amazone-groep bestaat vermoedelijk uit oorspronkelijk Guyaanse soorten èn echte Amazone-dieren ò uit soorten die uit het zuidelijker gelegen gedeelte van Brazilië afkomstig zijn. TATE (1939) heeft deze groep aangeduid als bestaande uit archaïsche elementen die wijd verspreid zijn en algemeen voorkomen. Volgens hem behoren $50 \%$ van de zoogdieren van de Guyana's tot deze categorie.

De bekende Amazone-reiziger Bates (1864) kwam tot de conclusie dat de fauna van noordelijk Pará aansluit bij die van Guyana en dat het zuidelijke Pará faunistisch behoort bij het Braziliaanse hoogland. ZERNY (1931) rekent zelfs het gehele stroomgebied van de Amazone tot het Guyana-district, ook de vlakte van de Orinoco. Deze onderzoeker geeft aan dat de Andes-fauna (het Colombiaanse district) afwijkt van die van de Guyana's en van Brazilië. Aan de andere kant heeft de Andesfauna ook een zekere relatie met deze twee gebieden; volgens ZERNY zou deze groter zijn dan de verwantschap tussen de fauna's van Guyana en Brazilië (zonder het Amazonegebied) onderling.

Uit deze beschouwingen zou zijn te concluderen dat het Amazonegebied vermoedelijk bevolkt is uit omliggende centra, zo als het Braziliaanse hoogland, Guyana en het Andesgebergte, na het tot land worden van het hier in geologisch jonge tijd nog bestaande mariene(?) bekken. Bovendien zouden hier nieuwe soorten zijn ontstaan en mede daardoor kan het Amazonegebied een zo grote soortenrijkdom verkregen hebben. 
Indien deze zienswijze juist is, dan zou dus de dierenwereld van Suriname niet voor de helft uit soorten bestaan afkomstig uit het Amazonegebied, maar dan zou de grote verwantschap te verklaren zijn uit een migratie van de fauna van het geologisch nude Guyana-schild naar het jonge Amazonegebied.

\section{S U M M A R Y}

\section{THE ZOOGEOGRAPHY OF SURINAM}

Little is known regarding the zoogeography of the Guyanas in general and of Surinam in particular. This brief survey is based on extant literature and new zoological material.

From an ecological point of view typical faunas may be distinguished for the coastal plain, the lowlands and the mountains of the interior, the savannas, and the rivers and creeks. The fauna of the coastal plain consists both of elements known from the interior, and of species found outside the country, some of them of Antillean origin. The lowland forest fauna shows a strong affiliation with that of the northern Amazon valley, whereas the mountains are populated with species related to Andean and Central American forms and with species from the lowlands of the Guyanas. The fauna of the savannas comprises elements of the savanna lands of Venezuela, the Greater Antilles, and Brazil, but includes as well a number of endemic species. The fauna of the rivers is composed of widely distributed neotropical reptiles, fishes, arthropods, and mollusks, and of many endemic species. There is some difference in the character of the fauna of the eastern and western rivers. Species of the Amazon tributaries may penetrate into the waters of French Guyana (Oayapok) and British Guyana (Essequibo), but the rivers of Surinam are isolated by the permanent watershed along the Brazilian border.

The five geographical groups observed in the fauna of Surinam may be represented by the following percentages: Amazonean, 40-50\%; Guyanean (endemic), 10-30\%; Andean, 20\%; Central American, 5\%; Antillean, 3\%. Thus, about half of all Surinamese species are Amazonean. According to BATEs and ZERNY, the fauna of the Amazon basin, and especially that of northern Pará, is Guyanean. The fauna of the Andes (Colombean district) differs in many respects from those of the Guyanas and southern Brazil, but on the other hand it has greater affinities with each of them than have the Brazilian and Guyanean faunas with one another.

It is probable that the Amazonean group is a mixed fauna consisting both of elements from the Guyanas, southern Brazil, and the Andes and of species originating in Amazonia itself. Hence, rather than assuming that the fauna of Surinam (and the other Guyanas) is composed for some $50 \%$ of Amazonean forms, it may be surmised that the Amazon basin has obtained its zoological population for a large part from the Guyanas. This supposition would seem to be supported by the fact that the Guyanas are geologically much older than the Amazon basin. 


\section{I T E R A T U U R}

Bates, H. W.: The Naturalist on the River Amazons. London, 1864.

Chapman, Fr. M.: Remarks on the life zones of Northeastern Venezuela .... Amer. Mus. Novitates I9I, 1925.

GeijSkes, D. C.: Het zoölogisch onderzoek van Suriname. Vakblad voor Biologen 33, 1953, p. 141-151.

Haverschmidt, F.: List of the birds of Surinam. Publ. Found. Sci. Research Surinam Neth. Ant. 13, Utrecht, 1955.

Parker, H. W.: The frogs, lizards and snakes of British Guiana. Proc. Zool. Soc. London 1935, p. 505-530.

Tate, G. H. H.: The mammals of the Guiana region. Bull. Amer. Mus. Nat. Hist. 76, 1939, p. 151-229.

ZERNY, H.: Ergebnisse einer zoologischen Sammelreise nach Brasilien .... VII. Lepidoptera: Die Syntomiden des Staates Pará. Ann. Naturhist. Museum Wien 45, 1931, p. 225-263.

Bou steent je

LODEWIJ K LENS, wiens naam als cartograaf van de Nederlandse Antillen nog te weinig bekendheid geniet, werd op 26 juni 1870 te Utrecht geboren. Hij bezocht de lagere school en de Rijks H.B.S. in zijn geboortestad en ging daarna naar Haarlem in opleiding voor de infanterie, waarbij zijn wens steeds was bij de miltaire verkenningen te worden geplaatst.

De eerste opdracht welke hij als le luitenant kreeg, was Drenthe in kaart te brengen. Zijn verzoek om na zijn promotie bij de verkenningen te mogen blijven, werd ingewilligd: Op 22 Maart 1905 vertrok hij als kaptein voor 5 jaar naar Curaçao om de A.B.C.-eilanden in kaart te brengen. (Zie Encycl. Nederl. West-Indië p. 533 en p. 760, 1916).

$\mathrm{Na}$ zijn terugkeer in Nederland kwam kapt. LeNs in Assen in garnizoen. Hier werd hem, op 24 Sept. 1910 - op aanbeveling van gouv. NUYENS - door de regiments-commandant kolonel J. F. N. VAN BUNGE, het ridderkruis der Oranje-Nassau Orde uitgereikt, als beloning voor de ijver en toewijding waarmede hij zich in De West van de hem opgedragen taak had gekweten. (Prov. Drentsche en Asser Crt 26 Sept. 1910).

Niet lang hierna nam kapt. LENS pensioen om zich wederom naar Curaçao te kunnen begeven. Na een grondige voorbereiding stichtte hij hier in 1912 op „Choloma” het bekende struisvogelpark „Albertine”, dat in 1931 ophield te bestaan.

Tijdens LENS' eerste verblijf op Curaçao was zijn oudste broer, de chirurg Dr P. C. TH. Lens, chef van het militaire hospitaal „Plantersrust". In het artikel dat hij over ,'Struisvogelteelt op Curaçao" (W.I. Gids, $I, 1919,2$, p. 3-12) schreef komt een afbeelding voor van de administrateur van ,Albertine" met zijn armen vol jonge struisen. - In 1907 bezocht hem voor enkele maanden op Curaçao zijn jongste zuster, de biologe A. D. LENS, die vele van de hierboven vermelde bijzonderheden verschafte.

LoDEwiJk Lens keerde in 1929 naar Nederland terug en stierf te Amsterdam op 7 juli 1949.

H. 